\title{
Prevalence of Subclinical Mastitis among Small Ruminants and Isolation of Some Etiological Bacterial Pathogens in Jimma Town, Ethiopia
}

\author{
Wakgari Abirham Hayle ${ }^{1 *}$, Rokeya Ahmed ${ }^{2}$ and Md. Ekhlas Uddin ${ }^{3}$ \\ ${ }^{1}$ College Veterinary Medicine and Animal Sciences, University of Gondar, Ethiopia; ${ }^{2}$ Dept. of Veterinary \& Animal \\ Sciences, Gono Bishwabidyalay, Dhaka, Bangladesh and ${ }^{3}$ Dept. of Biochemistry \& Molecular Biology, Gono \\ Bishwabidyalay, Dhaka, Bangladesh.
}

*Correspondence: bashirabirham@gmail.com

\begin{abstract}
Subclinical Mastitis in small ruminants is of concern due to the animal welfare, economic, public health, productivity, and livelihood impacts that it may pose. A cross-sectional study was conducted from October 2017 to April 2018 in and around Jimma town, Southwest, Ethiopia; to estimate the prevalence of subclinical mastitis, to isolate bacterial pathogens responsible for the occurrence of subclinical mastitis, and to identify risk factors associated with the development of subclinical mastitis in small ruminants. Milk samples were collected from 186 apparently healthy lactating small ruminants, tested on the field with the California Mastitis Test, and samples tested positive were subjected to bacteriological examinations. Out of 372 milk samples collected, 92(24.8\%) samples from 70 animals were positive by the California Mastitis Test and these were cultured on different media. Through bacteriological examinations, six isolates of bacteria were identified which include; $S$. aureus (8.1\%), S. epidermidis (10.2\%), S. intermidus (2.2\%), S. hyicus (1.6\%), S. agalactiae (3.2\%), and E. coli $(12.4 \%)$. The highest prevalence of subclinical mastitis recorded was due to Staphylococcus species (22\%) followed by E. coli (12.4\%) and the least prevalence was due to S. agalactiae (3.2\%). The overall prevalence of subclinical mastitis among small ruminants was 37.6\%. Age and parity number variations among small ruminants were found important in influencing the prevalence in statistically significant $(P=0.00)$ extents. The highest prevalence of subclinical mastitis was recorded in old (24.7\%) and in small ruminants having $>5$ parity numbers (24.7\%). The high prevalence of small ruminant subclinical mastitis in the study area suggests that intervention strategies their-goal-being prevention and control of subclinical mastitis should be designed; so as to improve the welfare of animals, to save people consuming the milk of small ruminants from zoonotic risks, and to harvest the diverse benefits that may be generated from small ruminant production.
\end{abstract}

Keywords: California Mastitis test, Prevalence, Subclinical mastitis, Small ruminants, and Zoonotic diseases.

\section{INTRODUCTION:}

Small ruminant production supplies wide range of products and services such as milk, meat, wool, hide and skin, immediate income generation and associated social functions for poor farmers in many parts of Ethiopia (Adane and Girma, 2008). Sheep and goats

UniversePG I www.universepg.com with their higher reproduction capacity, rapid growth rate, and their ability to give production in small and harsh environments are ideally suiting to produce by resource-poor smallholders (Tibbo, 2006).

Despite the huge sheep and goat population leading African countries in Ethiopia, small ruminant 
production and productivity and producers' benefits remain far below to the expectation due to continuously occurring production constraints such as disease, malnutrition, poor animal production system, reproductive inefficiency, management constraints, and general lack of veterinary care. Among these factors, disease takes great portions and could be caused by infectious and non-infectious agents (Tibbo et al., 2003). In dairy industry, udder health problem is one of the major diseases posing negative impacts on milk production, milk quality and animal welfare (Seegers et al., 2003).Among udder health problems, mastitis constitutes one of the major problems and is defined as an inflammation of the mammary glands characterized by changes in the physical and chemical features of milk and pathological changes in the glandular tissue often with non-specific and complex factors responsible for its occurrence (Radostits et al., 2007). It occurs worldwide in dairy animals and it has been described to have an extreme zoonotic and economic impact (AlMajali et al., 2008). Mastitis occurs in two forms in small ruminants namely: clinical mastitis and subclinical mastitis. Clinical mastitis occurs with the evidence of milk and udder changes. Subclinical mastitis could be only detected by indirect tests such as CMT, WST, milk SCC and pathogen isolation at laboratory (Ekhlas et al., 2014; Radostits et al., 2007; Uddin et al., 2017).

The prevalence of clinical mastitis is less than $5 \%$ in small ruminants, while the subclinical mastitis is much more common with a prevalence that ranges from 18 to $34 \%$ (Chingwen et al., 2002). Mastitis in small ruminants is mainly subclinical and results in decreased milk yield, may lead to growth retardation and higher mortality rate among suckling kid and lambs (McDougall et al., 2002).The most common causes of subclinical mastitis in most herds or flocks are bacterial in origin. The bacterial agents isolated from mastitic milk in small ruminants are mainly; Staphylococcus species, Streptococcus species, Pasteurella species, Pseudomonas species, Proteus species, Salmonella species, Corynebacterium species, Bacillus species and E. coli (Contreras et al., 2007). Among the bacterial agents, Staphylococcus species have been implicated as the leading causes of subclinical mastitis with higher prevalence in goat and sheep. Especially,
Coagulase-Negative Staphylococcus species (CNS) has been the most common reported cause of subclinical mastitis (Bergonier et al., 2003b).

Early diagnosis of subclinical mastitis is vital because changes in udder tissue take place much earlier than they become apparent. Various approaches, based on physical and chemical changes of milk and cultural isolation of organisms (gold standard) are practiced for the diagnosis of subclinical mastitis in small ruminants (Contreras et al., 2007). To diagnose the SCM, indirect tests such as CMT, WST and SCC are commonly used both in cows and small ruminants. White Side Test (WST) is also an indirect, easily applicable screening test for sub clinical mastitis in which $4 \%$ sodium hydroxide solution are used as reagent (Contreras et al., 2007).

Characterizing the etiology of bacterial infection is critical for understanding the grounds for establishing of infection and devising appropriate treatments to control the contagion. However, very little research has been done to explore the patterns of intramammary infections acquiring in small ruminants (Leitner et al., 2007). Therefore, this study was gird with the objectives of: To estimate the prevalence of subclinical mastitis among small ruminants in Jimma town, Southwestern, Ethiopia; to isolate bacterial pathogens responsible for the occurrence of subclinical mastitis in small ruminants; and to identify risk factors associated with the development of subclinical mastitis in small ruminants.

\section{Review of Literature}

2.1. Mastitis in Small Ruminants - The term mastitis was derived from the two Greek words "Mastos-"(for breast) and "-itis" (for inflammation) (Doğruer et al., 2010). It is one of the main udder problems and defined as an inflammation of the mammary glands characterized by changes in the physico-chemical features of milk and pathological changes in the glandular tissue often with non-specific and complex factors responsible for its occurrence (Radostits et al., 2007). In small ruminants, mastitis is a very significant disease that affects not only the meat and milk production, but also the well-being of shoats and human health as well (Abdullah, 2016; Tolone et al., 2016). 


\subsection{Types of Mastitis in Small Ruminants - Mastitis} are a disease that occurs in several different forms. Generally in animal, mastitis is divided into clinical and sub-clinical forms (Doğruer et al., 2010).

2.2.1. Clinical Mastitis - It occurs by having the evidence of both milk and udder changes with cardinal signs of inflammation upon physical examination, which includes swelling, pain, hotness (heat), redness, or necrosis of one or more halve udders and abnormal discharge of milk (presence of flakes or blood), as well as other systemic symptoms such as anorexia, fever or agalactia (Radostits et al., 2007). Usually the consequence of clinical mastitis is toxemia and gangrenous necrosis of the udder (Omaleki et al., 2011). The clinical syndrome can follow variable courses, ranging from hyper-acute to chronic. The occurrence of chronic disease may produce clinical pictures, which become gradually less clinically evident (Bergonier et al., 2003).

\subsubsection{Subclinical Mastitis in Small Ruminants -} Subclinical mastitis in small ruminants of Africa causes a significant impact on the production and productivity of dairy goat and sheep's due to its association with the absence of clinical signs to be detected by the clinicians or farmers. Lactating ewes/ does with subclinical mastitis does not show any clinical symptoms and giving apparently normal milk for long period which only known after indirect tests done and cultured with bacteriological examinations which makes them positive to mastitis (Kiossis et al., 2007). Identification of animal affected with subclinical mastitis is much more difficult than recognition of those with clinical mastitis. Detection of subclinical mastitis may require some additional indirect tests such as with CMT test, SCC and microbiological tests (Plummer and Plummer, 2011).

\subsection{Incidence and Etiology of Mastitis in Small}

Ruminants - Incidence of the clinical mastitis in small ruminant is usually below $5 \%$ and can lead to mortality or culling up to $90 \%$ of infected animal in the flock. However, in certain herds and flocks having of poor management system it may exceed 30\% (Goodridge et al., 2004). Mostly, sporadic cases of clinical mastitis are caused by Staphylococcus aureus, coagulase-negative Staphylococci (CNS), Arcanobacterium pyogenes,
Corynebacterium, Pasteurella species, and Pseudomonas species. Outbreak of clinical mastitis most frequently involves Staphylococcus species, Streptococcus species and other opportunistic agents such as Aspergillus species, Pseudomonas species, Burkholderia species, and Serratia species (Croft et al., 2000; Plummer and Plummer, 2011).

The most common cause of subclinical mastitis in most herds or flocks is bacterial in origin. Among them, Coagulase-Negative Staphylococcus species (CNS) have been implicated as the leading cause of subclinical mastitis with prevalence rates of $71 \%$ and $78 \%$, respectively, in goats and sheep. The second most common reported cause of subclinical mastitis is $S$. aureus, with reported prevalence rates of $8 \%$ in goats and 4\% in sheep (Bergonier et al., 2003b). Streptococcus species also have been isolated in cases of subclinical mastitis with prevalence rate ranges between $1.1 \%$ and $6.8 \%$ of subclinical mastitis cases (Mork et al., 2007; Hall et al., 2007; Ndegwa et al., 2001).

\subsection{Epidemiology of Small Ruminants Mastitis - In} dairy animals, mastitis causing pathogens are classified depending on their epidemiological behavior. However, such description is not as clear for small ruminants as it is for dairy cattle. During time of milking of the small ruminants, the likely source of CoagulaseNegative Staphylococci (CNS) are the skin on the teats along skin around the inner side of legs; thus, many CNS bacteria become persisted and long-term chronic infections (Piessens et al., 2011).CNS may leak out to the milk from the infected udder during milking and then spread via the milking equipment to other animals. Thus, the source of mastitis pathogens in small ruminants should not be assumed based simply on the behavior of these pathogens in dairy cows (Olechnowicz and Jaśkowski, 2014). The main reservoir of the contagious pathogens is the mammary gland. S. aureus and Str. Species are considered among the contagious pathogens. Consequently, these bacteria are spread from animal to other or between udders of the same animal during the milking process (Contreras et al., 2003). Apparently this refers to that $S$. aureusis germ capable of contaminating different surfaces and easily isolated from the skin and mucosa of the healthy animals. The role of environmental sources of $S$. 
aureus is less important than its presence in the mammary gland habitat, but may help in the spreading of infection from milking of the infected animal and milking machines or dairy workers can transmit it, but are not the origin of these infections. Generally, bacteria causing mastitis are often classified as "contagious"; if it is believed that the source of infection of milk is infected mammary glands with subclinical mastitis, or "environmental"; if the bacteria are considered to be opportunistic pathogens that normally reside in the environment around the animals (Ruegg, 2011).

\subsection{Important Causative Agents of Subclinical Mastitis in Small Ruminants}

\subsubsection{Bacterial Agents}

\section{Gram-positive agents}

Staphylococcus species - These species are Grampositive cocci, non-motile, non-spore forming, aerobic and facultative anaerobic bacteria. They are found in clusters like bunches of grapes and appear violet color when stained, catalase positive and usually oxidasenegative. Also, they could hydrolyse arginine and produce acetone and attack sugar by fermentation (Barrow and Feltham, 2004). Considering the fact that, S. aureus, Coagulase-negative Staphylococcus species (CNS) such as S. epidermidis, $S$. saprophyticus and $S$. intermidus are the important causative agents of subclinical mastitis in small ruminants (Windria et al., 2016).

Streptococcus species - These species are also Grampositive cocci in pairs or chains, non-motile, non-spore forming, aerobic and facultative anaerobic organisms. They are both catalase and oxidase negative, and ferment carbohydrate (Barrow and Feltham, 2004). Despite the pathological importance of Streptococci species in mastitis, they do not represent a group of especially prevalent pathogens on small ruminant flocks and are usually reported in somewhat less than $5-10 \%$ of cases of sheep and goats mastitis. However, they majorly cause clinical mastitis, and a number of epidemiological studies on subclinical mastitis even report the absence of these pathogens. This situation seems clearly different in certain areas of dairy small ruminant production, in which major problems on farms are diagnosed due to Str. agalactiae (Contreras et al., 2003).

Enterococcus species - Enterococcus species are Gram-positive cocci in pairs or short chains. They are non-motile (except few species), non-spore forming, aerobic and facultative anaerobic, catalase and oxidase-negative. They ferment carbohydrates (Barrow and Feltham, 2004). Those Gram positive bacteria are associated with mastitis in sheep, goat and cattle; include Enterococcus faecium and Enterococcus faecalis (Contreras and Rodríguez, 2011).

\section{Gram-negative agents}

E. coli - E. coli is Gram-negative rods, motile, aerobic and facultative anaerobic. Catalase-positive, Oxidasenegative, ferment sugars and produce gas (Barrow and Feltham, 2004). They are organisms commonly found in the environment in order to cause the coliform diseases and considered as opportunistic pathogen.

Pasteurella species - Pasteurella species are Gramnegative rods, non-motile, aerobic and facultative anaerobic. Usually, they are Catalase-positive, Oxidase-positive and can ferment sugar (Barrow and Feltham, 2004). The main source of infection from $P$. haemolytica for the teat of the ewe is the mouth of the lamb. In dairy sheep, where ewes are milked by hand or machine after lambs are removed, the incidence of $P$. haemolytica mastitis is dramatically reduced after lambs are weaned because there is no longer presence of organism on the teat of the ewe.

Mycoplasma species - Mycoplasma is a genus of bacteria that lack a cell wall around their cell membrane. They do not possess rigid cell walls, they are resistant to antibiotics such as penicillin, which interfere with the synthesis of bacterial cell walls. Mycoplasma species are the smallest bacterial cells yet discovered typically, about $0.1 \mu \mathrm{m}$ in diameter. It can be present in the milk of sheep and goats and can cause mastitis in the animal (Quinn and Markey, 2003). Contagious agalactia (CA) is a serious disease of small dairy ruminants that has a substantial economic impact on the goat and sheep milk industries. The main etiological agent of the disease is Mycoplasma agalactiae, although other species, such as Mycoplasma mycoides subsppcapri, Mycoplasma capricolum Sub 
spp. Capricolum and Mycoplasma putrefaciens, are pathogenic in goats (Contreras and Rodríguez, 2011).

\subsubsection{Viral Agents}

The mammary gland is more susceptible to injury by ovine progressive pneumonia virus (OPPV), nine of 15 experimentally infected sheep and all six naturally infected sheep had lympho-plasmacytic mastitis. Caprine arthritis-encephalitis virus (CAEV), like other Lentiviruses, causes a persistent lifelong infection. The CAEV induced subclinical infection in most goats. Most of infected does are likely to have a viral infection of the mammary gland, which is a target organ for the virus.

\subsubsection{Fungal Agents}

Cryptococcus neoformans which is yeast causes mastitis in cattle, buffaloes and experimentally in goats. Crytptococcus species inoculation into the glands of 10 goats resulted in mastitis in all of them but, there was no spread to the un-inoculated udder half. Mastitis may be acute with severe swelling of the gland and the supramammary lymphnodes, severe fall in milk yield and appearance of viscid mucoid gray white secretion. It is of public health importance especially where milk is taken without pasteurization since it causes human Cryptococcoses.

\subsection{Diagnosis of Mastitis in Small Ruminants}

\subsubsection{Physical Examination}

Visual examination and Udder palpation - Clinical examination of the small ruminant udder should be performed in order to palpate possible lesions on the skin of the udder and note visually color changes, injuries and nodules as well as changes in the general shape of the udder for example, increase in size and atrophy. Pain is one of clinical sign of the mastitic udder; therefore, any pain reaction during palpation should be noted. Furthermore the presence of nodules or hardness within the gland should be recorded. Each teat was held between the thumb and the index finger, and palpated throughout its length to evaluate its shape, size and consistency; teats of the same udder were compared with each other (Mavrogianni et al., 2004). Finally, the supra-mammary lymph nodes of the examined animal should be palpated, in order to detect possible alterations in size or consistency (Mavrogianni et al., 2005).

Visual examination of the mammary gland secretion - The first few streams of milk are to be drawn from the teat onto a paddle or on the palm of the gloved hand of the investigator. Expression of milk can be evaluated; for example, expression in drops can be indicative of teats enosis. Then, presence of abnormal features in mammary secretion (e.g., clots, flakes, tints) should also be recorded (Mavrogianni et al., 2004).

\subsubsection{Chemical Examinations}

Milk tests - There are various tests used to determine type of the causative organisms and the infection level of the herd or even individual animal. Wherefore making recommendations about a diagnostic test, it is important to consider the consequences of falsenegative and false-positive results. In the case of mastitis, the costs of treatment or culling of positive animals are important factors, and the aim is generally to reduce the overall prevalence of infection without necessarily eliminating the disease; therefore, specificity takes priority. However, to eliminate a disease, the sensitivity would have a higher priority than specificity (Clements et al., 2003; Lafi, 2006; Rahman et al., 2019). Appropriate tests include California Mastitis Test (CMT) and Somatic Cell Count (SCC) are regarded as the best indirect tests to diagnose intramammary infections (IMI) in both sheep and goats, when they are interpreted correctly (McDougall et al., 2001; Bergonier and Berthelot, 2003; Luengo et al., 2004; Persson and Olofsson, 2011).

Californian mastitis test (CMT) - The California mastitis test (CMT) is the quick and easy method used to detect subclinical mastitis. Agents in the reagent react with the DNA present in the epithelial and inflammatory cells to form a gel. The more DNA in the milk, the more gel is formed and the higher a count of the bacteria. The results are essentially subjected to assessment of the amount of gel, the degree of precipitation and gel formations are graded. The grades were: 0$)$ no precipitate; 1) trace precipitate; 2) distinct precipitate/weak gel formation; 3) distinct gel formation; and 4) strong gel formation. 
Somatic cell count (SCC) - The most common method for the detection of high bacteria counts in milk is the measurement of the somatic cell count (SCC), which gives an indication of whether an immune response to mastitis has begun in an animal. The numbers of epithelial and inflammatory cells (per $\mathrm{ml}$ ) are counted in a milk sample, usually taken on the 'test' days at regular intervals during lactation. The numbers of somatic cells indicate the degree to which an immune response has been mounted against organisms that cause intra mammary infections (IMI). The SCC can be regarded as a surrogate measure of mastitis (Barillet et al., 2001). It is important to know the threshold level of SCC because it has impact on the milk production and health of sheep and goats in dairy animals, current estimates in the range of 600,000 to 800,000 cells per $\mathrm{ml}$ indicate presence of infection and animal with less than 500,000 cells per $\mathrm{ml}$ are considered to be 'healthy' (Barillet et al., 2001).

Modified White side test (WST) - California Mastitis Test and Whiteside Test are recommended as threshold values for subclinical mastitis offering at least $93 \%$ accuracy of the diagnostic methods. In the WST, nucleic acids of the leucocytes of milk form a sodium salt with $0.4 \% \mathrm{NaOH}$ producing a gelatinous mass to which serum solids and fat globules become absorbed to produce the characteristic precipitate of the reaction.

\subsubsection{Bacteriological Examination of Milk Sample}

Bacteriological examination of milk samples remains the 'gold standard' for etiological diagnosis of the mastitis in small ruminants. Isolation of bacteria in pure culture and sufficient growth from only one milk sample from a ewe/doe with mastitis suffices to demonstrate the etiological role of these organisms in the disease (Contreras et al., 2007). Repeat samplings and bacteriological examinations are required only in following up efficacy of treatment regimes or monitoring control programs. The greatest advantage of bacteriological examination of milk samples is the possibility to demonstrate the etiological role of the isolated organisms in mastitis. Nevertheless, the method requires some time for definitive results and cannot be performed onsite (Fragkou et al., 2014). Specificity and positive predictive value were higher for post-milking samples than for pre-milking samples and false positive diagnoses were more frequent for UniversePG I www.universepg.com pre-milking samples. Post-milking samples should be used to diagnosis of small ruminant intra-mammary infection (Sánchez et al., 2004).

\subsection{Factors that Affects Occurrence and Timing of Onset of the Mastitis}

Various factors have been associated with the occurrence of mastitis in small ruminants such as parity, breed, udder halves, region and the number of lambs/ kids born. Notable suckling two or three lambs is associated with a greater mastitis risk than suckling only one lamb per ewe (Arsenault et al., 2008; Waage and Vatn, 2008). Factors related to the herd such as number of parity, stage of lactation and age, have been demonstrated to significantly influence prevalence of mastitis in goat and sheep; usually, infection rates are less frequent at the first kidding/lambing, and increase with age (McDougall et al., 2002; Moroni et al., $2005 \mathrm{~b}$ ). In addition, production forms and management practices may give rise to differences both in the epidemiology, bacteriology and clinical manifestations of mastitis. The timing of the onset of mastitis is important, in previous review of five studies by Bergonier et al., (2003); they reported that the majority of cases of mastitis occurred from the beginning of machine milking and during the first third of lactation.

\subsection{Economic Impacts of Mastitis in Small Ruminants}

Mastitis is of importance from three perspectives (Bergonier and Berthelot, 2003): hygienic, legal, and economic, that represent in reduced growth of lambs and their mortality, as well as mortality of ewes, treatment costs, reduced milk production and milk prices dependent on cellular quality in certain areas. The worldwide losses due to the disease are approximately $\$ 35$ billion annually (Bilal et al., 2004; Abdullah, 2016). Mastitis has a major impact on both economy and animal welfare in small ruminant production and associated with a reduction of milk yield and quality in ewe due both clinical and subclinical ewe's udder infection (Albenzio et al., 2002). While, mastitis caused by microbial infections in dairy goats reduces milk yield, modifies milk composition, and potentially contributes to morbidity in herds (Gutierrez-Chavez et al., 2016). In this context, manufacture of products from the meat and milk of small ruminants presents an 
opportunity to improve the economics of farming worldwide, thus, economic losses due to mastitis are of major concern to the dairy industry. Loss of milk quality caused by subclinical infection in dairy sheep has a negative effect on cheese manufacture (Abdelgawad et al., 2016).

\subsection{Treatment of Mastitis in Small Ruminants}

Treatment techniques of mastitis in small ruminant had been described by many hypotheses (Bergonier and Berthelot, 2003). Theoretically, the aim of 'in-lactation' treatment is the clinical and bacteriological cure of infected halves of clinically affected ewes with mastitis and functional recovery. In fact, for acute and per-acute mastitis, the aim is to avoid death and allow culling. In any case, affected animal must be removed from the dairy flock until culling or complete recovery. Antimicrobials are used in treatment of mastitis predominantly during lactation and, less frequently, during the dry period (Onni et al., 2011).

\subsubsection{Antimicrobial Therapy of Small Ruminant's} Mastitis - Bacterial infections are the predominant cause of both clinical and subclinical mastitis and antimicrobial agent remain a component of both mastitis treatment and control. The successful control depends on antibiotic treatments used. The use of antibiotics in food animals is under challenge, particularly use of broad spectrum, multi-component products and use of prophylactic treatment which should be practical and cost effective (Oliver et. al 2011). Using antibiotic in the treatment of clinical infections need selection of the most appropriate antibiotic and requires knowing the organism's identity, the organism's susceptibility to a particular antibiotic, the site of the infection (targeted tissue in present study is udder), individual factors of ewe/doe, the safety of the antibiotic in use and the cost of antibiotherapy (Shahen et al., 2019; Richard et al., 2012).

\subsubsection{Antibiotherapy of Small Ruminants Mastitis}

During Lactation Period - The major antibacterial used as treatments for mastitis have been directed against Gram-positive organism are particularly, Staphylococci and Streptococci. In addition, application of management practices that decrease the prevalence of contagious pathogens such as Strepto-

UniversePG I www.universepg.com coccus species and $S$. aureus has shifted the focus of mastitis control and economic losses to environmental pathogens that are associated with more frequent episodes of subclinical mastitis. That way, antibiotherapy should start immediately after detection of the first signs of the disease on mastiticudder and should be performed using effective antimicrobial agents (Erskine et al., 2003).

2.9.3. Dry-off Treatment of Mastitis - Indiscriminate use of antimicrobial agents can result in bacterial resistance and super infection, prophylactic use of antibiotics is restricted to clinical situations in which the benefits outweigh the potential risks. The use of antibiotics for the prevention is better than the treatment of infections and the duration of prophylaxis should be closely observed to prevent unnecessary antibiotic exposure (Richard et al., 2012). This prophylaxis program was applied in previous study by Kiossis et al., (2007) to test the effectiveness of a standard treatment for the control of subclinical mastitis during lactating period in a modern, commercial dairy sheep farm, resulted in limitation of subclinical mastitis during lactation and a better health status for udders entering the dry period. While the intra-mammary ampicillin dicloxacillin treatment had the best treatment rates, the combination of intramuscular amoxicillin clavulinic acid was also successful. Intramuscular amoxicillin-clavulinic acid as the sole treatment was not as effective as intra-mammary therapy (Doğruer et al., 2010).

\subsection{Control Techniques for Small Ruminants Mastitis}

The fight against mastitis should not be limited to treating isolated clinical episodes, but also requires the surveillance and control of both, clinical and subclinical mastitis (Paterna et al., 2014). The know-ledge of risk factors and etiological agents involved are also important in order to recommend specific and efficient control measures for both clinical and subclinical mastitis (Arsenault et al., 2008). Prevention of mastitis in small ruminants can be described upon programs that include vaccination, culling, application of good husbandry control and proper maintenance of milking machines, better milking routine without over milking and removal of clusters without impacts, and hygiene 
after milking. Improved techniques depend on a better understanding of the nature of predisposing factors and breeding for resistance are the approach that is considered as a sustainable methods for mastitis control (Conington et al., 2008).

\section{MATERIAL AND METHODS:}

3.1. Study Area - The current study was conducted from October, 2017 to April, 2018 in the Southwestern Ethiopia, in and around Jimma town, the capital of the Jimma zone. The town is about $346 \mathrm{KM}$ away from Addis Ababa, capital city of Ethiopia. It has a latitude and longitude of $7^{\circ} 40^{\prime} \mathrm{N} 36^{\circ} 50^{\prime} \mathrm{E} / 7.667^{\circ} \mathrm{N} 36.833^{\prime} \mathrm{E}$ respectively. The altitude of Jimma is 1780 meters above sea level (masl). It has a tropical rain forest climate with bimodal rainfall of the long annual wet season from March to October. The temperature at Jimma is in a comfortable range, with the daily mean staying between $20^{\circ} \mathrm{C}$ and $25^{\circ} \mathrm{C}$ year-round. The production system observed around the area was croplivestock mixed production system (CSA, 2010).
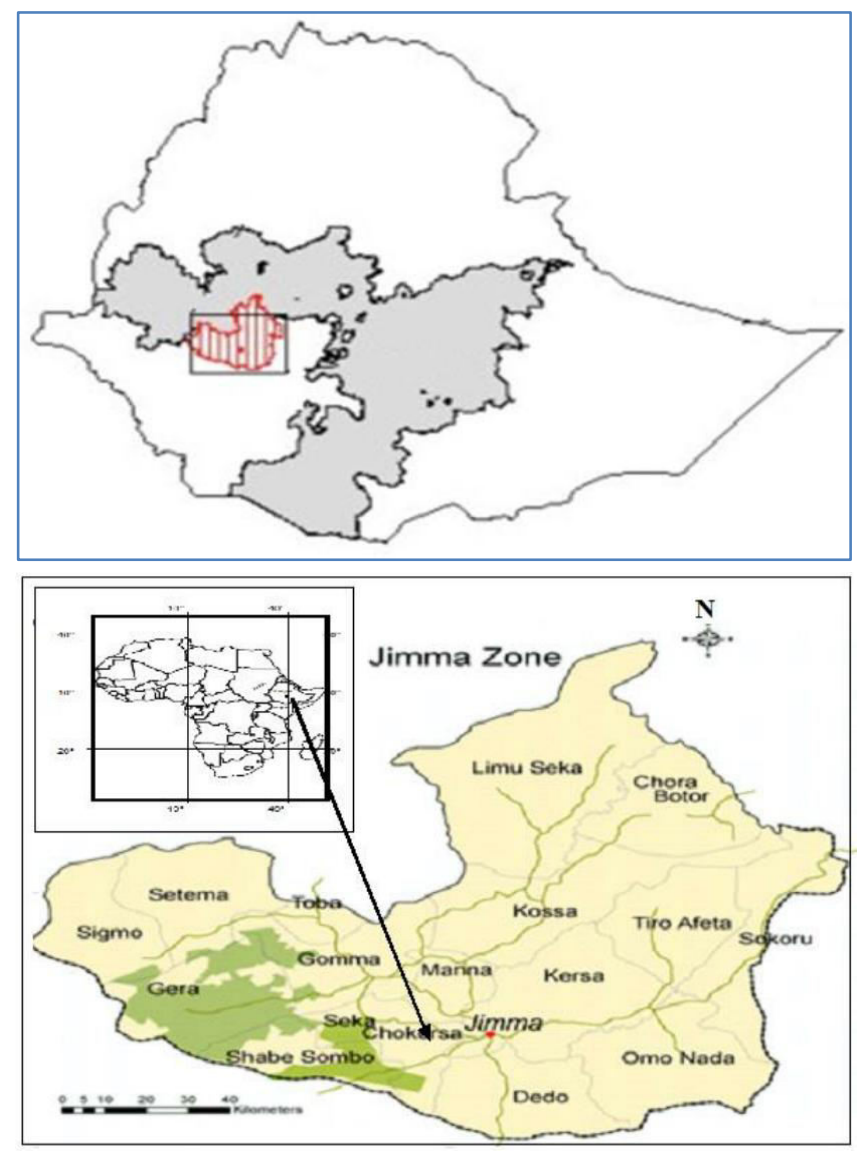

Fig 1: Map of the Jimma zone, Oromia regional state, Southwestern, Ethiopia.
Based on the 2007 census conducted by the Central Statistical Agency of Ethiopia (CSA), Jimma zone has total population of $2,486,155$ with an increase of $26.76 \%$ over the 1994 census, of which 1,250,527 are men and 1,235,628 women; with an area of 15,568.58 square kilometers. Jimma zone has a population density of 159.69 while 137,668 or $11.31 \%$ are urban inhabitants, a further 858 or $0.03 \%$ are pastoralists. According to the zone livestock and fisheries agency; Jimma zone has an estimated 1,718,284 heads of cattle, 466,154 sheep, 194,677 goats, 74,774 horses, 40,555 donkeys and 30,541 mules population (CSA, 2007).

3.2. Study Population - Animals included in this study were apparently healthy lactating local breeds and extensively managed small ruminants (sheep and goats) from selected four different districts in and around Jimma town, Jimma zone, Southwest, Ethiopia. A total of 186 small ruminants (75 sheep and 111 goats) from different districts and animals found at different age, stage of lactation, and parity numbers were considered. Small ruminant populations were classified in to three groups of age depending on their parity number which includes; adult groups for one to two parity, medium groups for three to four parity and older groups for five and above numbers of parity by asking the owners of animals.

3.3. Study Design - A cross sectional study was conducted from October, 2017 to April, 2018 in Southwestern Ethiopia, in and around Jimma town to estimate the prevalence of subclinical mastitis in small ruminants at the study area. In the current study, the districts found in Jimma zone were selected and grouped in a cluster, and within selected districts (Tiro Afeta, Kersa, Gumay and Jimma town) certain villages were selected according to simple random for milk samples collection.

3.4. Sample Size Determination - To determine the prevalence of small ruminant subclinical mastitis in and around Jimma town, an expected prevalence of $50 \%$ was taken into consideration. The sample size for the current study was determined by the epidemiological formula with $95 \%$ confidence interval and $5 \%$ absolute precision:

$\mathrm{n}=1.96^{2 *} \operatorname{Pexp} *(1-\mathrm{Pexp}) / \mathrm{d}^{2}$ 
Where: $\mathrm{n}=$ required sample size, Pexp $=$ expected prevalence, $1.96^{2}=95 \%$ confidence interval $\mathrm{d}^{2}=$ desired absolute precision. Based on the formula, the minimum sample size required was 384 from 192 target animals. However, in present study, since it is a dry season of the year from December to February months at the study area, it was impossible to collect 384 samples from the target population because of weaning of lambs and kids in the season the study was conducted. Therefore, maximum effort was exerted to get samples during the study period and a total of 372 milk samples were collected from 186 small ruminants.

3.5. Sampling Procedures/Methods - In the current study, apparently healthy lactating small ruminants were sampled to find the target disease by excluding the animals with physically injured udders. From a total of 186 apparently healthy lactating sheep and goats sampled in the study area, 372 milk samples were collected and tested with CMT reagent. During the time of sample collection from the animals, all necessary hygienic protocols were maintained in order to avoid false-positive and false-negative results.

3.5.1. Milk Sample Collection Procedures - Milk samples were collected according to the National Mastitis Council (NMC). After the udder halves have been washed with tap water, soap and dried with clean dry cloth, the teat ends were swabbed with cotton soaked in 70\% ethyl alcohol for purpose of disinfection. Then after, teat ends dried, the first three milking streams were discarded and approximately $10 \mathrm{ml}$ of milk was collected aseptically from each halves in to sterile test tube. Each sample was labeled legibly and accompanied by necessary identification information which includes date of sampling, species of the animals, type of sample, halves of udder, age of the animal, parity number, stages of lactation, and area from which the samples were taken.

3.5.2. Californian Mastitis Test (CMT) of Milk Samples - Milk samples taken from each udder halves were examined by CMT test and this screening test was conducted according to the standard procedure (Quinn et. al., 2002). In current study, all samples were examined on the field by using CMT reagent and CMT negative samples were decided by absence of gel form- ation and taking grade 0 and trace; then, they were recorded and discarded. However, CMT positive milk samples were whose moderately and highly form precipitation during mixed with CMT reagent and transported at $+4^{\circ} \mathrm{C}$ by packing within the icebox to laboratory for bacteriological tests and preservation purpose until procedures were completed according to the standard protocols with NMC.

3.6. Laboratory Procedures - In present study, laboratory procedures used were bacteriological tests. A loop full of CMT positive milk sample was streaked on blood agar base (Oxoid, UK) enriched with 5\% defibrinated sheep blood and nutrient agar, and then sub-cultured on selective media for different bacteria using the quadrant streaking method; Mannitol Salt Agar (MSA) for Staphylococcus species, Eosin Methylene Blue (EMB) Agar for E. coli and Edwards medium for Streptococcus species. In addition, the samples were also cultured on MacConkey Agar (MA) for differentiation. All the plates were incubated aerobically at $37^{\circ} \mathrm{C}$ for $24-48$ hours. Then, the plates were examined for gross colony morphology, pigmentation and hemolytic characteristics at $24-48 \mathrm{hrs}$. For further identification of the organisms, different biochemical tests (Gram stain, Catalase test, Coagulase test, Indole test, Motility test and O-F tests) were conducted (Quinn et. al., 2002).

\subsection{Methods of Data Management and Analysis -}

The collected data was checked, coded and entered in to Microsoft Excel Work Sheet and analyzed by using SPSS 20 software. Descriptive statistics like frequency and percentage were also calculated to describe small ruminant subclinical mastitis prevalence and compareison of the degree of association between risk factors was done by using chi-square $(\chi 2)$ test. In all the cases, 95\% confidence interval and 5\% absolute precision errors were considered.

A P-value $<0.05$ was used to verify statistically significance difference and when the P-value was found to be $\geq 0.05$, the difference in prevalence was considered insignificant. The prevalence of subclinical mastitis was calculated according to both the number of the collected samples and total number of the sampled animals described separately. 


\section{RESULTS:}

4.1. Prevalence of Small Ruminant Subclinical Mastitis and its Association With Risk Factors From a total of 186 apparently healthy lactating sheep and goats considered, 70(37.6\%) of them were found to be infected with subclinical mastitis based on CMT. And out of a total of 372 milk samples collected, 92 (24.8\%) of the samples from 70 small ruminants were positive for CMT and bacteriological tests. During the study period, potential risk factors such as species of animals, age, parity numbers and lactation stage were taken in to consideration to estimate the association with the occurrence of the subclinical mastitis in small ruminants.

\subsubsection{Occurrence of Subclinical Mastitis between} Species of Animals - Among 75 and 111 sheep and goats species respectively tested with CMT and bacteriological tests, some of them tested positive and others negative with $(\mathrm{P}=0.107)$. Observed results indicated that, species as a risk factor is statistically not significant with occurrence of subclinical mastitis in small ruminant populations at study area with a total prevalence of $37.6 \%$ (Table 1).

Table 1: Overall prevalence of small ruminant subclinical mastitis between species of the animals

\begin{tabular}{|l|l|l|l|l|l|l|}
\hline Species & No of +Ve & No of - Ve & Total & \% of +Ve & \% of -Ve & P-Value \\
\hline Sheep & 23 & 52 & 75 & 12.4 & 28 & \\
\hline Goat & 47 & 64 & 111 & 25.3 & 34.4 & \\
\hline Total & 70 & 116 & 186 & 37.7 & 62.4 & 0.107 \\
\hline
\end{tabular}

Note: $\mathrm{No}$ of $+\mathrm{Ve}=$ Number of positive, No of $-\mathrm{Ve}=$ Number of negative, $\%$ of $+\mathrm{Ve}=$ percentage of positive, $\%$ of $\mathrm{Ve}=$ percentage of negative.

Table 2: Subclinical mastitis between age categories and among parity numbers of small ruminants

\begin{tabular}{|l|l|l|l|l|l|l|}
\hline \multirow{2}{*}{$\begin{array}{c}\text { Risk } \\
\text { factors }\end{array}$} & \multirow{2}{*}{$\begin{array}{c}\text { No of animal } \\
\text { examined }\end{array}$} & $\begin{array}{c}\text { No of +Ve } \\
\text { animals }\end{array}$ & No of -Ve animals & \multicolumn{2}{c|}{ Percentage } & \multirow{2}{*}{ P-Value } \\
AGE & & & & & & \\
\hline Adult & 49 & 9 & 40 & 4.8 & 21.5 & \\
\hline Medium & 61 & 15 & 46 & 8.1 & 24.7 & \\
\hline Old & 76 & 46 & 30 & 24.7 & 16.2 & \\
\hline Total & 186 & 70 & 116 & 37.6 & 62.4 & 0.000 \\
\hline Parity & & & & & & \\
\hline $1-2$ & 49 & 9 & 40 & 4.8 & 21.5 & \\
\hline $3-4$ & 61 & 15 & 46 & 8.1 & 24.7 & \\
\hline$\geq 5$ & 76 & 46 & 30 & 24.7 & 16.2 & \\
\hline Total & 186 & 70 & 116 & 37.6 & 62.4 & 0.000 \\
\hline
\end{tabular}

Note: $\mathrm{No}$ of $+\mathrm{Ve}=$ number of positive, № of $-\mathrm{Ve}=$ number of negative, $\%$ of $+\mathrm{Ve}=$ percentage of positive, $\%$ of $-\mathrm{Ve}=$ percentage of negative.

\subsubsection{Occurrence of the Subclinical Mastitis among} Different Age Categories of Animals - In the study, the difference in age among small ruminants was found to be greatly associated with the occurrence of subclinical mastitis in small ruminants $(\mathrm{P}=0.00)$. Out of the 186 animals, $49(26.3 \%)$ were adult and $9(4.8 \%)$ of them were showed positive result for subclinical mastitis of the small ruminant at study area. While among sampled population, 61 (32.8\%) were medium and $15(8.1 \%)$ animal numbers showed positive result UniversePG I www.universepg.com for SCM of sheep and goats. Also, from 186 sample small ruminants, $76(40.9 \%)$ were in older group and out of them $46(24.7 \%)$ were found positive for subclinical mastitis.

\subsubsection{Occurrence of Small Ruminant Subclinical} Mastitis among Parity Numbers - In present study, parity number of the target population were grouped according to their number of lambs/kids gave by asking the owners. Animals were classified in to 3 
classes of groups like age and described. Parity number of animals was found to influence prevalence of subclinical mastitis in statistically significant state $(\mathrm{P}=0.00)$. For this study, parity numbers and ages of animal were more related to each other based on information gathered from animal owners about number of lambs/kids they gave to them and decision to the age of ewe/doe was made based on their parity numbers (Table 2).

\subsubsection{Occurrence of Small Ruminant Subclinical} Mastitis among the Stages of Lactation - Out of 186 healthy lactating does and ewes, 63 (33.9\%), 69 $(37.1 \%)$ and $54(29 \%)$ at their early, mid and late lactation stages respectively and showed differences in subclinical mastitis (Fig 1). The prevalence of subclinical mastitis among lactation stages of small ruminants was different but was not statistically significant $(\mathrm{P}=0.09)$.

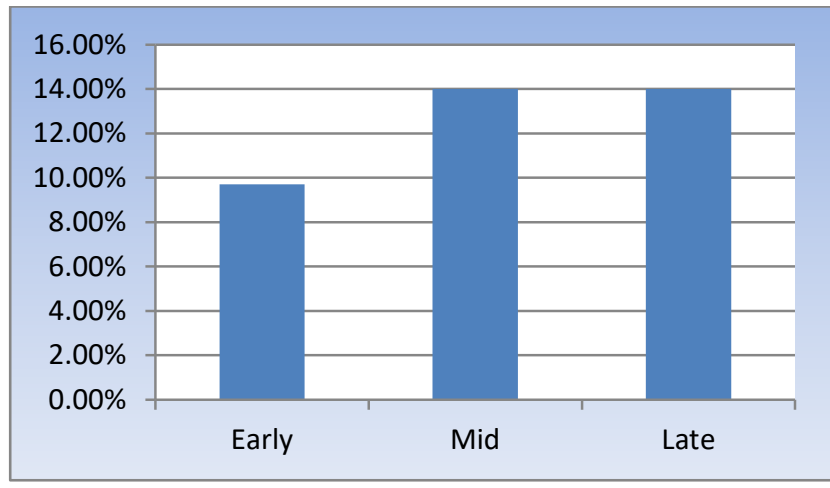

Fig 2: Graphical presentation of SCM prevalence in small ruminants among lactation stages.

\subsubsection{Prevalence of Small Ruminant Subclinical} Mastitis based on the CMT Test - In current study, 186 healthy lactating sheep and goats were subjected to CMT, out which 70 (37.6\%) animals were positive for CMT, based on degree of gel formation. From 186 animals, 372 milk samples were collected and examined, out of which $92(24.8 \%)$ were positive with CMT (Fig 2). However, these 92 samples were taken from right halve positive and left halve negative or vice versa and/or both halves positive of the 70 sheep and goats. Due to this reason, the overall prevalence calculation was used rather than individual udder halves' prevalence calculation. And the overall prevalence of the subclinical mastitis based on CMT result was estimated to be $37.6 \%$.

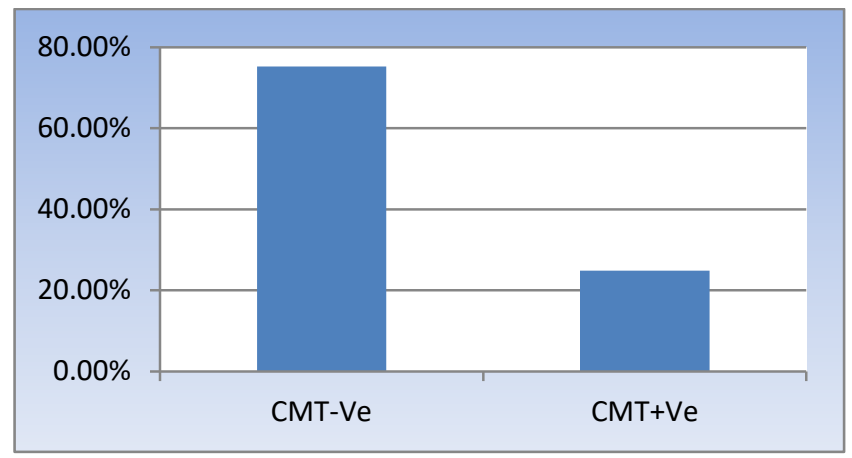

Fig 3: Graphical presentation of prevalence of SCM in small ruminants based on CMT result.

4.1.6. Prevalence of Gram Positive Bacteria in Small Ruminant Subclinical Mastitis - All of the 70(37.6\%) CMT positive samples were cultured at bacteriology laboratory on different media, out of which 47(67.1\%) samples were positive for Gram positive bacteria based on their Gram stain result.

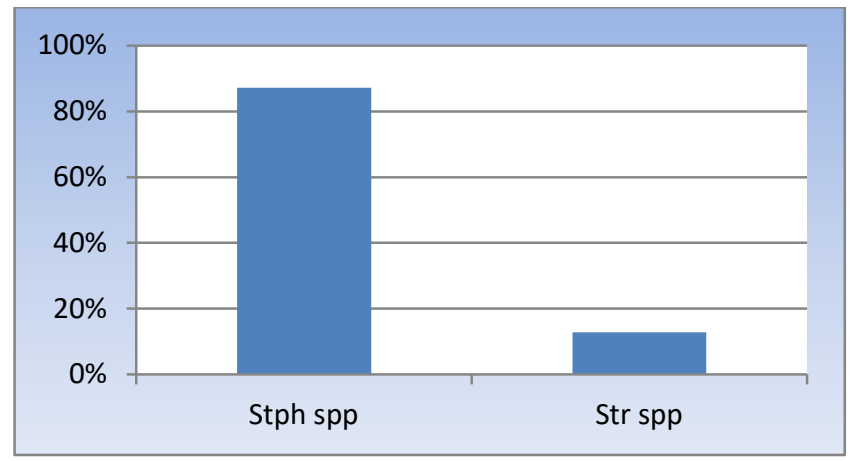

Fig 4: Graphical presentation of the percentage of Staphylococcus species and Streptococcus species in Gram positive bacterial agents from CMT positive samples (Where: Stphspp = Staphylococcus species,

Strspp $=$ Streptococcus species.

In consideration of individual bacterial isolates, from 41(87.2\%) Staphylococcus species 15(36.6\%), $19(46$. $4 \%), 3(7.2 \%)$ and $4(9.8 \%)$ were $S$. aureus, S. epidermidis, $S$. hyicus and $S$. intermidus respectively. And among 6(12.8\%) of Streptococcus species, 6(100\%) of them were $S$. agalactiae, isolated based on the basic standard procedure of bacteriology laboratory.

In the present study, the total population prevalence of SCM caused by Staphylococcus species was $22 \%$ and the prevalence of Streptococcus species was 3.2\%. However, the overall prevalence of SCM in small ruminant caused by Gram positive bacteria in study area was $25.2 \%$. 


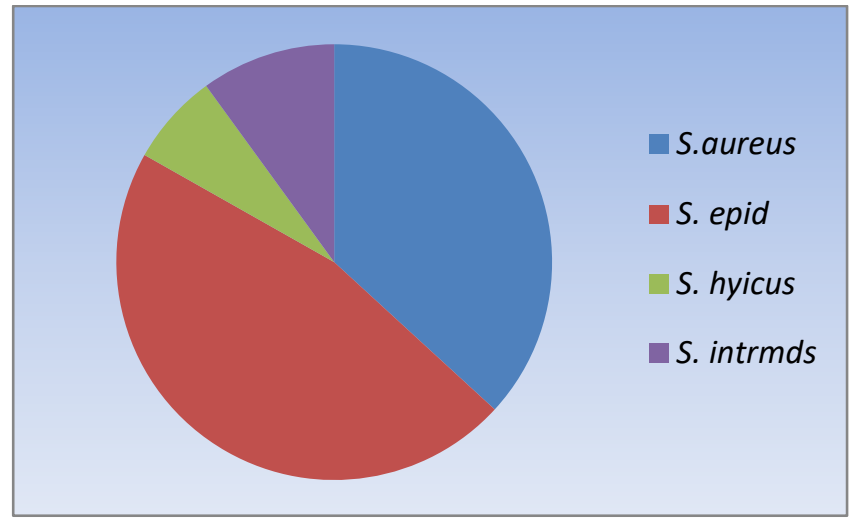

Fig 5: Graphical presentation of the prevalence of isolated Staphylococcus species in CMT positive samples from target population.

\subsubsection{Prevalence of Gram Negative Bacteria in Small Ruminant Subclinical Mastitis - Out of the} 70(37.6\%) CMT positive samples cultured at bacteriology laboratory, 23(32.9\%) of them had taken Gram negative staining characteristics and the isolated species of bacteria was $E$. coli, with a prevalence of $12.4 \%$, as all stained samples were positive by further biochemical tests done.

\section{DISCUSSION:}

The overall $37.6 \%$ prevalence recorded of subclinical mastitis among small ruminants in the study area was found to closely agree with prevalence reported by Chingwen et al., (2002), who reported the prevalence of SCM in sheep and goats to be between $18 \%$ and $34 \%$. Out of 75 lactating ewes, $23(30.6 \%)$ of them shown positive result for the subclinical mastitis. The total prevalence of target disease in small ruminant population at study area was recorded as $12.4 \%$. This infection prevalence is relatively lower when compared with reports in other countries like Jordan (24.8\%) by Almajali et al., (2003), Iran (39\%) by Batavani et al., (2003), and Portugal (70\%-92\%) by Quiroga et al., (2003). The prevalence difference observed might be due to geographical variation, breed differences, management system they follow and there was no machine milking system in present study. For this reason, present finding is not agreed with above reports. However, the current result was more related with finding of the Gebrewahid et al., (2012), who reported the prevalence of SCM in sheep as $(10.6 \%)$ in Kefeta Humera and Tanqua Abergelle districts in Tigray regional state, North Ethiopia. In UniversePG I www.universepg.com order to found result, present report is closely agreed with mentioned above finding in Ethiopia based on similar management system and procedures done to examine the target populations.

In case of goat species, $111(59.7 \%)$ were examined and $47(42.3 \%)$ does were found to be positive for SCM among sampled goats and overall small ruminants population prevalence of SCM recorded was $25.3 \%$ at study area. The result demonstrated in this study was greatly lower than the findings reported by Adwan et al., (2005) 52\% in Palestine, Swai et al., (2008) $51.1 \%$ in Tanzania, and 56\% in Nigeria. However, the prevalence recorded in current study was moderately closed to different reports with overall prevalence of $27.3 \%$ and $28.7 \%$ in Vermont (USA) (McDougall et al., 2002) and in Kenya respectively. But, overall recorded prevalence of the present study in goat was slightly higher than those reported in Ethiopia 18.0\% (Gebrewahid et al., 2012) and in South Ethiopia 15.5\% (Megersa et al., 2009). All mentioned above differences might be due to many reasons such as; variation in number of sampled animals, difference in host breed and management system risk factors and in present study, there was no machine milking of target populations which might expose the animals to intra-mammary infection.

In present study, age of the animals is considered as one of the important forceful risk factors and clearly significant difference $(\mathrm{P}=0.00)$ was found between the three groups animal age which were grouped according to their parity number. The highest prevalence of SCM infections were recorded in does and ewes found at older age with prevalence of $24.7 \%$. While, medium class of age was infected at second level with rate of $8.1 \%$ and lastly, adult age groups were affected at lower level of SCM with population prevalence of $4.8 \%$.

In this study, the total target animal prevalence of SCM at study area was $37.6 \%$. Present result show that, it is in negotiation with previous reports by McDougall et al., (2002) and Moroni et al., (2005b) which sate that, usually the prevalence of mastitis are less frequent at the first kidding/lambing and increased with age at parallel; i.e higher risk of mastitis were reported in older age of group. 
In current study, stages of lactation were also considered as one of the important risk factors and three lactation stages were used, i.e early, mid and late lactation stage. Though, animals at the early lactation stage were less infected with total population prevalence of $9.7 \%$ and both animals at mid and late lactation stages were found at equal prevalence of infection in target population of $14 \%$. Present report showed that, the rate of SCM occurrence in small ruminants was increased with prolonged lactation. This result was found to be in agreement with previous reports of Leungo et al., (2004) and Moroni et al., (2004). However, there was no significant statistical association between development of SCM and stages of lactation $(\mathrm{P}=0.09)$ at the study area. In present report, based on the CMT test done on field at animal side, the prevalence of SCM in sampled animals was $24.8 \%$ as the 92 number of samples collected were positive from 70 sheep and goats out of the 186 total populations. In current study, the overall small ruminant subclinical mastitis according to CMT test at target area was recorded as $37.6 \%$. This result is higher when compared with report discussed by Haftay et al., (2014) in Aba'lla district, Afar region the prevalence of SCM reported was $20.6 \%$. This difference might be due to environmental variation, methodologies used and breed differences.

The prevalence of subclinical mastitis caused by Gram positive bacteria in 186 sampled animals at target area was $67.1 \%$. At genus level, $41(87.2 \%)$ and $6(12.8 \%)$ Staphylococcus species and Streptococcus agalactiae were identified respectively. Among Staphylococcus species, there was higher prevalence of Coagulasenegative Staphylococci (CNS) i.e Staphylococcus epidermidis at rate of $46.3 \%$ followed by Staphylococcus aureus at prevalence of $36.6 \%$, Staphylococcus intermidus at rate of $9.8 \%$ and finally Staphylococcus hyicus at $7.3 \%$ were isolated from CMT positive samples. The total population prevalence of SCM at study area caused by S. epidermidis, S. aureus, S. intermidus and S. hyicus were $10.2 \%$, $8.1 \%, 2.2 \%$ and $1.6 \%$ respectively. The present result was found more related and in agreement with previously reported findings in Spain. However, the prevalence of $S$. aureus in present result is far lower than the report of Winter, (2009) for years 1998 to

UniversePG I www.universepg.com
2003, the prevalence of $S$. aureus were reported between $20.8 \%$ and $46.6 \%$ as pathogen of the small ruminant subclinical mastitis. This gap might be due to environmental variation, difference in the management system of the flocks, methodologies used, breed variation, number of animals tested and there was no machine milking in present study. Due to this reason, current result is not in agreed with report of Winter, (2009).

The other Gram positive bacteria isolated in current study was Streptococcus agalactiae with the prevalence in Gram positive organism of $12.8 \%$ and overall population prevalence of SCM at target area by Str. agalactiae was $3.2 \%$. Present result is found in agreement with previous reports of Mork et al., (2007), Leitner et al., (2007), Hall et al., (2004) and Ndegwa et al., (2001). In current study, isolated Gram negative bacteria causing SCM in small ruminant at study area was E. coli at total population prevalence of $12.4 \%$. Despite of this, certain studies have reported that Gram negative bacteria rarely induce SCM in sheep and goats and present result is found less related with Gebrewahid et al., (2012) report on E. coli as its prevalence was $17.0 \%$ reported in Tigray regional state, North Ethiopia. Due to this reason, both results are less agreed. However, the current result is higher than Mbindyo et al., (2014) report of the E. coli prevalence in Kenya was 3\%. But, present study is lower when compared with report of Iqbal et al., (2004) as he was reported the prevalence of E. coli in small ruminant $25 \%$. This difference might be due to geographical variation, tests used in the methodology, exposure rate of hosts to the bacteria, management system of the flocks and there was no machine milking in present study.

\section{CONCLUSION AND RECOMMENDATIONS:}

The current study estimated a high prevalence of small ruminant subclinical mastitis, occurred due to some bacterial pathogens such as S. aureus, S. epidermidis, S. intermidus, S. hyicus, Str. agalactiae and E. coli with considerable prevalence. The highest prevalence of subclinical mastitis in target population was caused by Staphyloccocus species followed by E. coli and the lowest prevalence was estimated in Streptococcus agalactiae. The high prevalence of small ruminant 
mastitis in the study area may be associated with the lack of community awareness about the disease and the less attention given by professionals. Due to this reason, reported prevalence of small ruminant subclinical mastitis will be very important with regards to animal welfare, economic loss, and public health aspects. Among the risk factors considered (i.e. species, age, stage of lactation and parity numbers) in target population, age and parity number of the animals were indicated to influence the prevalence of subclinical mastitis in statistically significant condition. Based on the above conclusion, the following recommendations are forwarded:-

$>$ Since milk was observed to be consumed only by elders and sometimes by diseased children; community awareness should be performed about the risks associated with consumption of milk of small ruminants, and how to maintain proper udder hygiene before and after milking.

$>$ Subclinical mastitis can cause growth retardation in small ruminants which may lead to poor meat and carcass quality, hide and skin, and wool production; and thus, sheep and goats should be given attention and proper diagnoses and treatment practices be practiced.

$>$ As the older age groups and higher parity numbers are mostly affected classes, owners should remove such animals on time from their flocks, so as to minimize the risks of pathogen distribution.

$>$ Further research should be conducted with emphasis given to the epidemiology of the disease and molecular characterization of infectious pathogens responsible for its occurrence.

\section{ACKNOWLEDGEMENTS:}

First of all, I would like to provide my great gratitude for the almighty God. I am highly impressed to express my heartfelt thanks and gratitude to University of Gondar, College Veterinary Medicine and Animal Sciences for its effort in designing externship programs. I would like to extend my thanks to Jimma University, School of Veterinary Medicine, microbiology laboratory staff workers for their patience, permission and delivery full information during my research works. Last but not least, I would forward my heartfelt thanks to my advisor, Dr. Abebe Belete who helped me by devoting his time to read and correct this study manuscript and to enable me finish all my works by solving the many challenges I encountered.

\section{CONFLICTS OF INTEREST:}

The Authors declare there is no competing interest to publish the present research study.

\section{REFERENCES:}

1. Abdelgawad, A.R., Rovai, M., Caja, G., Leitner, G. and Castillo, M. (2016). Evaluating coagulation properties of milk from dairy sheep with subclinical intramammary infection using near infrared light scatter. A preliminary study: J. of Food Engineering, 168: 180-190.

https://doi.org/10.1016/j.jfoodeng.2015.07.018

2. Abdullah, A. H., (2016). Study the Inhibitory Effect of Aqueous Extract of Punicagranatum L. on resistant Staphylococcus aureus isolate from mastitic milk. Journal for Veterinary Medical Sciences, 5(2): 1-8.

3. Adane, Y., Girma, A. (2008). Economic significance of sheep and goats production handbook for Ethiopia.

4. Adwan, G., Abusafieh, D., Aref, R. and Omar, A. (2005). Prevalence of microorganisms associated with intramammary infection in cows and small ruminants in the north of Palestine Journal of the islamic university of gaza, 13(1):165-173.

https://journals.iugaza.edu.ps/index.php/IUGNS/ article/view/219

5. Albenzio, M., Taibi, L., Muscio, A., and Sevi, A. (2002): Prevalence and etiology of subclinical mastitis in intensively managed flocks and related changes in the yield and quality of ewe milk. Small Ruminant Research, 43(3): 219-226.

6. AlMajali, A. M., Al-Qudah,K. M., Al-Tarazi, Y. H. and Al-Rawashdeh,O. F. (2008). Risk factors associated with camel brucellosis in Jordan. Journal of Tropical Animal Health Production, 40: 193-200. 
7. AlMajali, A. M. and Jawabreh, S., (2003). Period prevalence and etiology of subclinical mastitis in Awassi sheep in southern Jordan. Small Ruminant Research, 47: 243-248. https://doi.org/10.1016/S0921-4488(02)00259-6

8. Arsenault, J., Dubreuil, P., Higgins, R., and Bélanger, D. (2008). Risk factors and impacts of clinical and subclinical mastitis in commercial meat-producing sheep flocks in Quebec, Canada. Preventive Veterinary Medicine, 87(3): 373-393.

9. Barillet, F., Rupp, R., Mignon-Grasteau, S., Astruc, J.M. and Jacquin, M. (2001). Genetic analysis for mastitis resistance and milk somatic cell score in French Lacaune dairy sheep. Genetics Selection Evolution, 33(4): 397-416. https://doi.org/10.1186/1297-9686-33-4-397

10. Barrow, G. and Feltham, R.K. A., (2004). Cowan and Steel's Manual for the Identification of Medical Bacteria: Cambridge University Press, UK.

11. Batavani, R.A., Mortaz, E., Falahian, K., Dawoodi, M.A. (2003). Study on frequency, etiology and some enzymatic activities of subclinical bovine mastitis in Urmia, Iran. Small Ruminant Research, 50: 45-50.

12. Bergonier, D., Crémoux, D.E., Rupp, R., Lagriffould, G. and Berthelot, X. (2003b): Mastitis of Dairy Small Ruminants. Veterinary Research, 34(5): 689-716.

https://pubmed.ncbi.nlm.nih.gov/14556701/

13. Bergonier, D. and Berthelot, X., (2003): New advances in epizootiology and control of ewe mastitis. Livestock Production Science, 79(1): 1-16.

14. Bergonier, D., de Cremoux, R., Rupp, R., Lagriffoul, G. and Berthelot, X. (2003). Mastitis of dairy small ruminants. Veterinary Research, 34(5): 689-716.

15. Bilal, M., Iqbal, M., Muhammad, G., Avais, M. and Sajid, M. (2004). Factors affecting the prevalence of clinical mastitis in buffaloes around Faisalabad district (Pakistan). International Journal of Agriculture \& Biology, 6(1): 185-187.

http://www.fspublishers.org/published_papers/3 3582_..pdf

UniversePG I www.universepg.com
16. Central Statistical Agency (CSA), (2007): Federal Democratic Republic of Ethiopia: Central Statistical Investigation Abstract.

17. Central Statistical Agency (CSA), (2010): Federal Democratic Republic of Ethiopia: Central Statistical Investigation Abstract.

18. Chingwen, Y., Han-tsung, W. and Jih-tay, H. (2002). Relationship of somatic cell count, physical, chemical and enzymatic properties to the bacterial standard plate count in dairy goat milk. Journal of Livestock Production Science, 74: 63-77. https://doi.org/10.1016/S0301-6226(01)00290-1

19. Clements, A.C., Taylor, D.J., and Fitzpatrick, J.L. (2003). Evaluation of diagnostic procedures for subclinical mastitis in meatproducing sheep. Journal of Dairy Research, 70(02): 139-148.

20. Conington, J., Cao, G., Stott, A. and Bünger, L. (2008). Breeding for resistance to mastitis in United Kingdom sheep, a review and economic appraisal. The Veterinary Record, 162(12): 369-376.

https://doi.org/10.1136/vr.162.12.369

21. Contreras, A., Luengo, C., Sanchez, A. and Corrales, J. (2003). The role of intramammary pathogens in dairy goats. Livestock Production Science, 79(2): 273-283.

22. Contreras, A., Sierra, D., Sánchez, A., Corrales, J., Marco, J., Paape, M. and Gonzalo, C. (2007). Mastitis in small ruminants. Small Ruminant Research, 68(1): 145-153.

23. Contreras, G.A. and Rodríguez, J.M., (2011). Mastitis comparative etiology and epidemiology. Journal of Mammary Gland Biology and Neoplasia, 16(4): 339-356.

https://link.springer.com/article/10.1007/s10911 -011-9234-0

24. Croft, A., Duffield, T., Menzies, P., Leslie, K., Bagg, R. and Dick, P. (2000). The effect of tilmicosin administered to ewes prior to lambing on incidence of clinical mastitis and subsequent lamb performance, Journal of Can Veterinary, 41: 306-311.

25. Doğruer, G., Saribay, M.K., Ergün, Y., Aslantaş, O., Demir, C. and Ateş, C.T. (2010). Treatment of subclinical mastitis in Damascus 
goats during lactation. Small Ruminant Research, 90(1-3): 153-155.

26. Ekhlas Uddin Md., Pulak Maitra, Firoz Alam Md., (2014). Isolation and characterization of proteases enzyme from locally isolated $\mathrm{Baci}$ llus sp., Amer. J. of Life Sci., 2(6), 338-344. https://doi.org/10.11648/j.ajls.20140206.12

27. Erskine, R.J., Wagner, S. and De Graves, F.J., (2003). Mastitis therapy and pharmacology. Veterinary Clinics of North America: Food Animal Practice, 19(1): 109-138.

28. Fragkou, I. A., Boscos, C.M. and Fthenakis, G.C. (2014). Diagnosis of clinical or subclinical mastitis in ewes. Small Ruminant Research, 118(1-3): 86-92.

29. Gebrewahid, T.T., Abera, B.H. and Menghistu, H.T. (2012). Prevalence and Etiology of Subclinical Mastitis in Small Ruminants of Tigray Regional State, North Ethiopia. Veterinary World, 5(2): 103-109.

https://doi.org/10.5455/vetworld.2012.103-109

30. Goodridge, L., Hill, A. and Lencki, R. (2004). A review of international standards and the scientific literature on farm milk bulk-tank sampling protocols. Journal of Dairy Science, 87(9): 3099-3104.

31. Gutiérrez-Chávez, A., Martínez-Ortega, E., Valencia-Posadas, M., and Corona, J. (2016): Potential use of $B$. thuringiensis bacteriocins to control antibiotic-resistant bacteria associated with mastitis in dairy goats. Folia Microbiologica, 61(1):11-19. https://doi.org/10.1007/s12223-015-0404-0

32. Haftay, A., Habtamu, T. M. and Abebe, M.S. (2014). Bacterial identification and antimicrobial susceptibility of subclinical mastitis causing bacteria from goats in Aba'lla district in Afar, North-Eastern Ethiopia.

33. Hall, S.M. and Rycroft, A.N., (2007). Causative organisms and somatic cell counts in subclinical intra mammary infections in milking goats in the UK. Veterinary Records, 160:19-22. https://doi.org/10.1136/vr.160.1.19

34. Iqbal, M., Khan, M.A., Daraz, B. and Siddique, U. (2004). Bacteriology of mastitic milk and in vitro antibiogram of the isolates. Pakistan Veterinary Journal, 24(4): 161-164.
35. Kiossis, E., Brozos, C., Petridou, E. and Boscos, C. (2007). Program for the control of subclinical mastitis in dairy Chios breeds ewes during lactation. Small Ruminant Research, 73(1): 194-199.

https://doi.org/10.1016/j.smallrumres.2007.01.0 $\underline{21}$

36. Lafi, S., (2006): Use of somatic cell counts and California Mastitis Test results from udder halves milk samples to detect subclinical intramammary infection in Awassi sheep. Small Ruminant Res., 62(1): 83-86.

37. Leitner, G., Merin, U., Lavi, U., Egber, A. and Silanikove, N. (2007). Aetiology of intramammary infection and its effect on milk composition in goat flocks. Journal of Dairy Animals Research, 74: 186-193. https://doi.org/10.1017/S0022029906002299

38. Luengo, C., Sánchez, A., Corrales, J.C., Fernández, C. and Contreras, A. (2004). Influence of intramammary infection and non-infection factors on somatic cell counts in dairy goats. J. of Dairy Research, 71(02): 169-174.

39. Mavrogianni, V.S., Fthenakis, G., Burriel, A., Gouletsou, P., Papaioannou, N. and Taitzoglou, I. (2004). Experimentally induced teat stenosis in dairy ewes: clinical, pathological and ultrasonographic features. Journal of Comparative Pathology, 130(1): 70-74.

40. Mavrogianni, V.S., Fthenakis, G.C., Brooks, H., Papaioannou, N., and Saratsis, P. (2005). The effects of inoculation of Mannheimia haemolytica into the teat of lactating ewes. Veterinary Research, 36(1): 13-25.

https://europepmc.org/article/med/15610720

41. Mbindyo, C.M., Gitao, C.G. and Bebora, L. (2014). A cross-sectional study on prevalence of subclinical mastitis and Antimicrobial susceptibility patterns of the bacterial isolates in small holder dairy goats in Kenya. Vol: (II).

https://www.researchgate.net/publication/26438 2267

42. McDougall, S., Pankey, W., Delaney, C., Barlow, J., Mardough, P.A. and Scruton, D. (2002). Prevalence and incidence of subclinical mastitis in goats and dairy ewes in 
Vermont, USA. Small Ruminant Research, 46: 115-121.

43. McDougall, S., Murdough, P., Pankey, W., Delaney, C., Barlow, J. and Scruton, D. (2001). Relationships among somatic cell count, California mastitis test, impedance and bacteriological status of milk in goats and sheep in early lactation. Small Ruminant Research, 40(3): 245-254.

https://europepmc.org/article/med/11323209

44. Megersa, B., Tadesse, C., Abunna, F., Mkibib, B. and Debela, E. (2009). Occurrence of mastitis and associated risk factors in lactating goats under pastoral management in Borana, Southern Ethiopia. International J. of Applied Res-earch Veterinary Medicine, 42(6): 12491255.

45. Mork, T., Waage, S., Tollersrud, T., Kvitle, B. and Sviland, S. (2007). Clinical Mastitis in ewes: Bacteriology, Epidemiology and Clinical features. Acta Veterinary Scandinavica, 49: 23.

46. Moroni, P., Pisoni, G., Ruffo, G., Cortinovis, I. and Casazza, G. (2005b). Study of intramammary infections in dairy goats from mountainous regions in Italy. New Zealand Veterinary Journal, 53(5): 375-376.

https://europepmc.org/article/med/16220137

47. Moroni, P.F., Vellere, M., Antonini, G., Pisoni, G., Ruffo, P. and Carli, S. (2004). Antibiotic susceptibility of coagulase-negative staphylococci isolated from goats milk. International Journal of Antimicrobial Agents, 23: 637-640.

48. Ndegwa, E.N., Mulei, C. M. and Munyua, S.J. (2001). Prevalence of microorganism's associated with udder infections in dairy goats on small-scale farms in Kenya. J.l of South African Veterinary Association, 72: 97-98.

49. Olechnowicz, J. and Jaśkowski, J.M. (2014). Mastitis in small ruminants. Medycyna Weterynaryjna, 70(02): 67-72.

50. Oliver, S.P., Murinda, S.E. and Jayarao, B.M. (2011). Impact of antibiotic use in adult dairy cows on antimicrobial resistance of veterinary and human pathogens: a comprehensive review. Food borne Pathogens and disease, 8(3): 337-355.

51. Omaleki, L., Browning, G.F., Allen, J.L. and Barber, S.R. (2011). The role of Mannheimia species in bovine mastitis. Veterinary Microbiology, 153(1): 67-72. https://doi.org/10.1016/j.vetmic.2011.03.024

52. Onni, T., Sanna, G., Larsen, J. and Tola, S. (2011). Antimicrobial susceptibilities and population structure of Staphylococcus epidermidis associated with bovine mastitis. Veterinary Microbiology, 148(1): 45-50.

53. Paterna, A., Contreras, A., Gómez-Martín, A., Amores, J., and De la Fe, C. (2014). The diagnosis of mastitis and contagious agalactia in dairy goats. Small Ruminant Research, 121(1): 36-41.

54. Persson, Y. and Olofsson, I., (2011). Direct and indirect measurement of somatic cell count as indicator of intramammary infection in dairy goats. Acta Veterinaria Scandinavica, 53(15): $1-5$.

https://doi.org/10.1186/1751-0147-53-15

55. Piessens, V., Van-Coillie, E., Verbist, B., Supré, K., Braem, G., and De-Vliegher, S. (2011). Distribution of coagulase-negative Staphylococcus species from milk and environment of dairy cows differs between herds. Journal of Dairy Science, 94(6): 2933-2944.

56. Plummer, P. J. and Plummer C., (2011). Diseases of the mammary gland in sheep and goat. A text book of veterinary medicine $2^{\text {nd }}$ ed. Pugh-Baird editors: Elsevier and August.

57. Quinn, P.J. and Markey, B.K., (2003). Concise Review of Veterinary Microbiology. Blackwell Publishing Ltd. The Atrium Southern Gate, Chichester, West Sussex, PO19 8SQ, Oxford, UK.

58. Quinn, P.J., Carter, M., Markey, B.K. and Carter, G.R. (2002). Clinical veterinary microbiology. Harcourt Publishers, Virginia, Pp: 331-344.

59. Quiroga, M.C., Marcelion, P.P., Espadaneria, E.M. andVilela, C.L. (2003). Survey of mastitis in sheep: a preliminary study. Veterinary Tecnica; 7: 52-55.

https://www.cabi.org/ISC/abstract/19972207410 
60. Radostits, O.M., Gay, C.C., Hinchcliff, K.W. and Constable, P.D. (2007). Mastitis in veterinary medicine: A text book of disease of cattle, sheep, pigs, goats, and horses. $10^{\text {th }}$ ed. London: Ballier Tindall. Pp: 674-762.

61. Rahman MA, Ahmad T, Mahmud S, Uddin ME, and Ahmed R. (2019). Isolation, identification and antibiotic sensitivity pattern of Salmonella spp. from locally isolated egg samples, Am. J. Pure Appl. Sci., 1(1), 1-11. https://doi.org/10.34104/ajpab.019.019111

62. Richard, A.H., Michelle, A., Clark, Finkel, R., Jose, A., Rey, Karen, W. and Champe, R. (2012). Lippincott's Illustrated Reviews Pharmacology $5^{\text {th }}$ edition. Lippincott-Raven.

63. Ruegg, P.L., (2011). Mastitis in smallruminants. $44^{\text {th }}$ Annual Conference of the American Association of Bovine Practitioners, Small Ruminant Session: September 22-25, 2011, St. Louis MO: 1-26.

64. Sánchez, A., Contreras, A., Corrales, J.C. and Muñoz, P. (2004). Influence of sampling time on bacteriological diagnosis of goat intramammary infection. Veterinary Microbiology, 98(3-4): 329-332.

https://pubmed.ncbi.nlm.nih.gov/15036542/

65. Seegers, H., Fourichon, C. and Beaudeau, F. (2003): Production effects related to mastitis and mastitis economics in dairy cattle herds. Veterinary Research, 34(5): 75-91.

66. Shahen MZ, Mahmud S, Uddin ME and Alam MS. (2019). Effect of antibiotic susceptibility and inhibitory activity for the control of growth and survival of microorganisms of extracts of Calendula officinalis, Eur. J. Med. Health Sci. 1(1), 1-9.

https://doi.org/10.34104/ejmhs.0190109

67. Swai, E.S., Mobise E. and Mtui P. F. (2008). Occurrence and factors associated with udder infections in small holder lactating dairy goats in Arumeru district, Tanzania, Veterinary Investigation Center. Livestock Research Rural Development, 12: 1-12.

68. Tibbo, M., (2006). Productivity and health of indigenous sheep breeds and crossbreds in central Ethiopian, Highlands. PhD dissertation.

69. Tibbo, M., Mukasa-Mugera, and Rrga, J.E.O. (2003). Risk factors for mortality associated with respi-ratory disease among Menz and Horo sheep and goats in Ethiopia. Ethiopian Veterinary Journal, 165: 276-287.

https://europepmc.org/article/med/12672374

70. Tolone, M., Mastrangelo, S., Di Gerlando, R., Sutera, A.M., Monteleone, G., Sardina, M.T. and Portolano, B. (2016). Association study between $\beta$-defens in gene polymorphisms and mastitis resistance in Valle del Belice dairy sheep breed. Small Rumi. Res, 136: 18-21.

71. Uddin M. E., Ahmad T., and Ahammed T. (2017). Thermotolerant extracellular proteases produced by $B$. subtilis isolated from local soil that repre-senting industrial application. J. of Pure and Applied Microbiol. 11(2), 733-741. https://doi.org/10.22207/JPAM.11.2.12

72. Waage, S. and Vatn, S., (2008). Individual animal risk factors for clinical mastitis in meat sheep in Norway. Preventive Veterinary Medicine, 87(3-4): 229-243.

73. Windria, S., Widianingrum, D.C. and Salasia, S.I.O. (2016). Identification of Staphylococcus aureus and Coagulase Negative Staphylococci isolates from mastitis milk of Etawa crossbred goat. Research J. of Microbiology, 11(1): 11.

74. Winter, P. (2009). Praktischer Leitfaden Mastitis: Vorgehenbeim Einzeltier und im Best and. Stuttgart: Parey, Pp: 254. https://www.eurobuch.com/buch/isbn/97838304 $\underline{41687 . h t m l}$

Citation: Hayle WA, Ahmed R, and Uddin ME. (2020). Prevalence of subclinical mastitis among small ruminants and isolation of some bacterial pathogens in Jimma Town, Ethiopia, Eur. J. Med. Health Sci., 2(6), 107-124. https://doi.org/10.34104/ejmhs.020.01070124 (C) क 